Sains Malaysiana 49(12)(2020): 3037-3044

http://dx.doi.org/10.17576/jsm-2020-4912-15

\title{
Effect of Shock Wave on Constant Load Behaviour of Pb-Free/CNT Solder Joint
}

(Kesan Gelombang Kejutan terhadap Kelakuan Beban Malar Sambungan Pateri Bebas Pb/CNT)

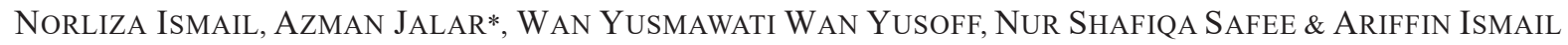

\begin{abstract}
The constant load behaviour of SAC305 solder joint with addition of carbon nanotube (CNT), exposed to shock wave condition was investigated. Formulated SAC305-CNT solder pastes with $0.04 \mathrm{wt}$. \% CNT were manually printed to the printed circuit board (PCB) with copper surface finish to form solder joint. The solder joint was exposed to the shock wave condition via open field blast air test using Trinitrotoluene (TNT) explosive. Nanoindentation approach was used to determine the constant load behavior of the SAC305-CNT solder joint under shock wave condition. The results showed that addition of CNT reduced the indentation depth of SAC305 solder joint at $10 \mathrm{mN}$ peak load for blast test sample and control sample. Indentation depth displacement of SAC305-CNT solder joint for blast test sample and control sample were reduced about $\sim 42$ and $\sim 56 \%$, respectively, if compared to the SAC305 solder joint for blast test sample and control sample. SAC305-CNT solder joint was experienced minimal changes of stress exponent when exposed to the shock wave. The existence of CNT in the solder joint slows down the depth displacement due to constant load.
\end{abstract}

Keywords: Carbon nanotube; constant load behaviour; SAC305-CNT; shock wave; solder joint

\section{ABSTRAK}

Kelakuan beban malar sambungan pateri SAC305 dengan penambahan karbon nanotiub (CNT) yang didedahkan kepada keadaan gelombang kejutan telah dikaji. Pes pateri SAC305-CNT yang diformulasi dengan $0.04 \%$ bt. CNT telah dicetak secara manual ke atas papan litar pencetak (PCB) berkemasan kuprum untuk menghasilkan sambungan pateri. Sambungan pateri yang didedahkan kepada keadaan gelombang kejutan melalui ujian letupan udara padang terbuka menggunakan bahan letupan Trinitrotoluena (TNT). Pendekatan pelekukan nano digunakan untuk menentukan sifat kelakuan beban malar sambungan pateri SAC305-CNT pada keadaan gelombang kejutan. Keputusan menunjukkan penambahan CNT mengurangkan kedalaman pelekukan sambungan pateri SAC305-CNT pada beban puncak $10 \mathrm{mN}$ untuk sampel ujian letupan dan sampel kawalan. Perubahan kedalaman pelekukan sambungan pateri SAC305CNT bagi sampel ujian letupan dan sampel kawalan masing-masing telah berkurang sebanyak $\sim 42$ dan $\sim 56 \%$ jika dibandingkan dengan sambungan pateri SAC305 bagi sampel ujian letupan dan sampel kawalan. Sambungan pateri SAC305-CNT mengalami perubahan eksponen tekanan yang minimum apabila didedahkan kepada gelombang kejutan. Kehadiran CNT di dalam sambungan pateri memperlahankan perubahan kedalaman akibat beban malar.

Kata kunci: Gelombang kejutan; karbon nanotiub; kelakuan beban malar; SAC305-CNT; sambungan pateri

\section{INTRODUCTION}

Solder joint is the essential part in the electronic chip package in which its function is to provide the electrical connection and mechanical integration between the components in the electronic package. The integrity and reliability of the solder joint influence the reliability of the electronic products. Exposure to the harsh environment such as in automotive, electronics, and military application devices tend to degrade the mechanical properties of solder joint. This is due to the several factors such as temperature and vibration. Therefore, it is vigorous to study solder joint reliability during service in these specific environments, to predict the life of electronic products (Han et al. 2012). Due to the rapid development of the electronic industry, electronic products are increasingly becoming miniaturized and multi-functional. In the miniaturization scale, the components in the electronic devices transform to smaller size and the properties of the components are distinctly different from the conventional components (Jiang et al. 2019). The evaluation of mechanical properties of solder joint included hardness, yield strength, shear strength, and creep properties in the harsh environment 
at a small scale are needed due to different properties gap. Stability of mechanical properties such as creep and related constant load behaviour is essential in order to estimate the reliability of the package. Creep is one of the properties that get attention which refer to the slow, permanent deformation of materials under external loads or stress. From the creep analysis study, we may know the resistance of the materials to the creep and can estimate the lifetime of the materials (Kassner 2009).

Fabrication of composite solder by addition of nanoparticles is introduced to enhance the mechanical properties of the solder. Nanoparticles that were used included metal and non-metal such as $\mathrm{Zn}, \mathrm{Ni}, \mathrm{Al}$, titanium oxide, graphene, and carbon nanotubes (CNT) (Huang et al. 2016; Zhang \& Tu 2014). Since CNT have a great mechanical property which is known to have more than $\sim 10-500 \mathrm{GPa}$ of strength, addition of CNT in composite solder become a great interest in order to get its superior strength (Mallakpour \& Khadem 2016). Many researchers reported the enhancement of mechanical properties in solder by the addition of CNT (Ismail et al. 2019; Kumar et al. 2008; Zhongbao et al. 2014). Attention on the constant load behaviour including creep properties of composite solder with addition of CNT also reported. Yang et al. (2018) studied the creep behaviour of Sn-Bi solder joint reinforced by CNT by performed the tensile test. They found that addition of CNT refines the microstructure and improved the creep resistance of that solder joint. The improvement of creep behavior is due to existence of CNTs could provide more obstacles for dislocation pile-up, which enhances the values of the stress exponent and the creep activation energy. Niranjani et al. (2014) performed the nanoindentation test to investigate the creep properties of $\mathrm{Sn} 3.8 \mathrm{Ag} 0.7 \mathrm{Cu}$ (SAC387) lead free solder with addition of $0.05,0.1$ and 0.5 wt. $\%$ of single wall carbon nanotube (SWCNT). They found that increasing in the weight percentage of SWCNT resulted in the increasing of hardness as well as reduction in the steady state creep rate, primary creep stage displacement and primary creep stage time.
On the other hand, only few attempts have been made on creep properties research in harsh environments, particularly in high shock conditions due to high costs (Wan Yusoff et al. 2019). In military, application of electronic devices exposes them to the high shock condition during the operation. Electronic devices are important for communication and guidance for modern unmanned vehicular applications. Therefore, it is vital to seek and understand the creep properties of the solder joint by exposing it to the harsh environment. In this paper, we focus on the effect of harsh environment from blast test to produce shock wave on the constant load behaviour of SAC-CNT solder joint using nanoindentation approach.

\section{MATERIALS AND METHOD}

In this study, experimental procedure was divided into three subsections which is: fabrication of SAC305-CNT solder joint, open air field blast test, and microstructural observation and nanoindentation test. Experimental procedures are similar to the previous published work by Ismail et al. (2020).

\section{FABRICATION OF SAC305-CNT SOLDER JOINT}

SAC305-CNT solder paste was formulated by mechanically mixing of $96.5 \mathrm{Sn}-3.0 \mathrm{Ag}-0.5 \mathrm{Cu}$ (SAC305) solder powder size range $20-38 \mu \mathrm{m}$ with no-clean fluxes and CNT. Solder powder and no-clean fluxes were provided by Red Ring Solder (Malaysia) Sdn. Bhd. CNT nanoparticles with $\sim 10 \mathrm{~nm}$ diameters were obtained from Nanotubes, USA. Compositions of CNT used is 0.04 wt. $\%$. Mixture of SAC305 solder powder, CNT and noclean flux was stirred about 5 min and then mixing in the vacuum chamber for about two hours to make sure the homogeneity. Fabricated solder pastes namely as SAC305-CNT. Figure 1 shows the illustrated SAC305-CNT solder paste fabrication. Formation of solder joint was performed by manually printing the solder paste on the printed circuit board (PCB) using stencil printing. Printed solder pastes on PCB board with $\mathrm{Cu}$ surface finish then

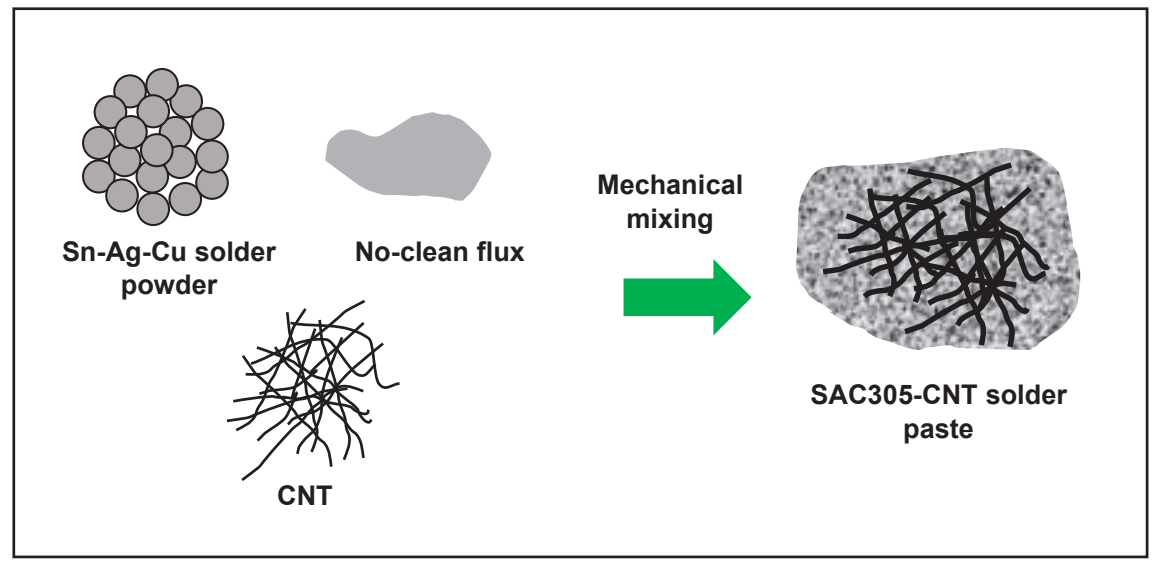

FIGURE 1. Illustration of fabrication SAC305-CNT solder paste 
reflow using reflow oven with peak temperature $260{ }^{\circ} \mathrm{C}$. Soldered samples of SAC305 and SAC305-CNT were indicated in Figure 2. Selected part of samples indicated in Figure 2 were then cut into a small size $(2 \mathrm{~mm} \times 1 \mathrm{~mm}$ size $)$.

\section{FIELD AIR BLAST TEST}

Open field air blast test was conducted at explosive research area by explosion expert from National Defence University of Malaysia. Trinitrotoluene (TNT) explosive type or call as plastic explosive (PE) with $1000 \mathrm{~g}$ of weight charge was used in this test. Soldered samples were covered with the satin cloth and then located on the wooden stand. Soldered samples were placed about $2 \mathrm{~m}$ from the blast source. Pressure probe was used to measure the shock wave pressure produced by the blast test. Shock wave and peak amplitude of the pressure was analysed using BLASTDAQ Post Processing software. Detected shock pressure has been mentioned in previous work by Wan Yusoff et al. (2019). For $1000 \mathrm{~g}$ weight charge of explosive, $32 \mathrm{MPa}$ amplitude shock wave with acceleration time of 7 ms has been generated.

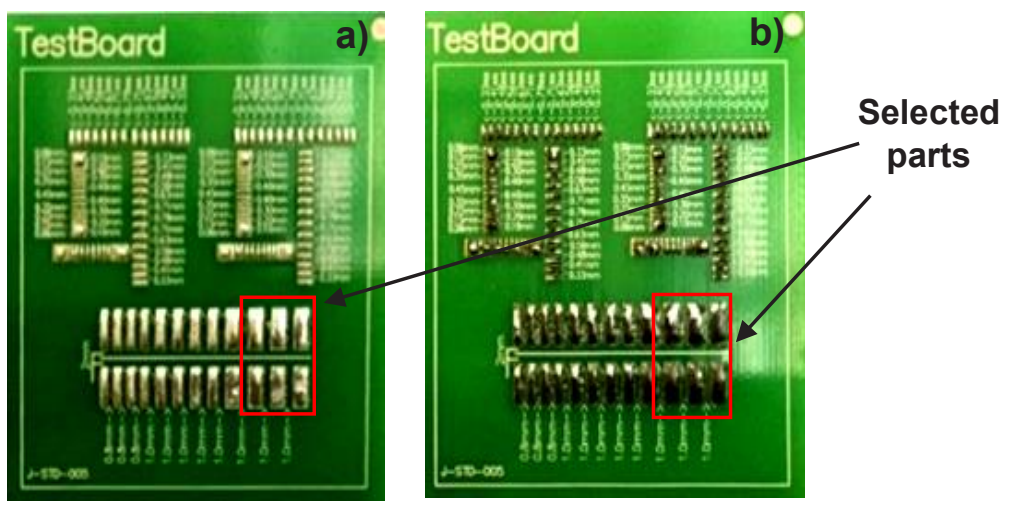

FIGURE 2. Soldered samples of a) SAC305 b) SAC-CNT on $\mathrm{Cu}$ substrate

\section{MICROSTRUCTURAL OBSERVATION AND} NANOINDENTATION TEST

After the blast test was done, soldered samples were then carried out to the lab for further analysing. Sample preparation was performed for blasted samples before underwent microstructural observation and nanoindentation test. The samples go through metallography technique including mounting, grinding, and polishing to produce a smooth surface. For microstructural observation, selected sample was observed under field emission scanning electron microscope (FESEM) Carl Zeiss brand Model Gemini SEM 500 with energy dispersive $\mathrm{X}$-Ray (EDX) mapping and analysis.

Nanoindentation test was performed at room temperature using a diamond Berkovich indenter on a Nano Test nanoindentation testing platform (MicroMaterials Ltd., UK). Three indentations have been made on the solder matrix of the solder joint as shown in Figure 3.

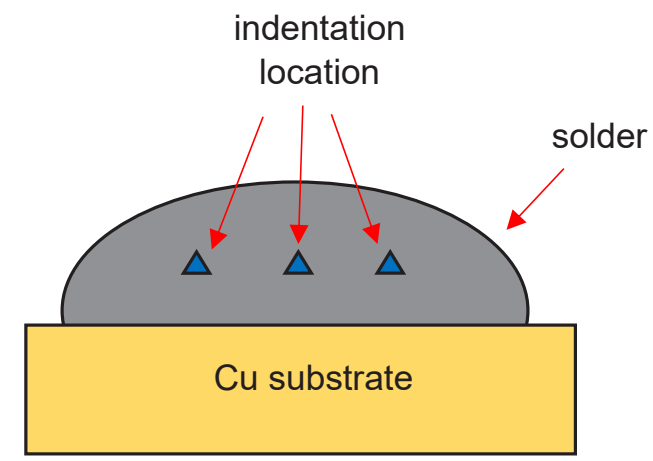

FIGURE 3. Schematic of indentation location in the solder matrix of the solder joint 
Applied load of $10 \mathrm{mN}$ with loading and unloading rates of $0.5 \mathrm{mNs}^{-1}$ and up to $60 \mathrm{~s}$ dwell time were applied during the indentation test. Constant load behaviour was determined by plot the indentation depth versus dwell time data from the loading-unloading $(P-h)$ profile. (Goodall \& Clyne 2006). Further analysing of constant load behaviour was conducted by plotted the log-log graph of strain rate versus stress using the following equations:

$$
\begin{aligned}
& \sigma=\frac{F}{A_{P}} \\
& \dot{\varepsilon}=\frac{1}{h} \frac{d h}{d t}
\end{aligned}
$$

where $\sigma$ is stress; $\mathrm{F}$ is applied load; $A_{p}$ is indentation projected area; $h$ is depth; $d h$ is depth gradient; and $d t$ is time gradient. $A_{P}$ for Berkovich indenter is $24.5 h^{2}$.

\section{RESULTS AND DISCUSSION}

Figure 4(a) and 4(b) shows the FESEM image of SAC305CNT solder joint with the EDX mapping and analysis. As previously established, addition of CNT in the SAC305 solder matrix did not formed the new phase due to CNT did not chemically interact with the solder elements (Ismail et al. 2020). Therefore, SAC305-CNT solder matrix consists of $\beta$-Sn primary phase, near eutectic phase ( $\mathrm{Ag}_{3} \mathrm{Sn}$ and $\beta$-Sn) and $\mathrm{Cu}_{6} \mathrm{Sn}_{5}$ intermetallic compound as reported by others researcher (Sun \& Zhang 2015). Figure 4(a) indicated the distribution of $\mathrm{Sn}, \mathrm{Ag}, \mathrm{Cu}$, and carbon elements in the marked spot area of SAC305-CNT solder matrix. From the EDX mapping, existence of carbon elements showed that the distribution of CNT in the solder matrix.

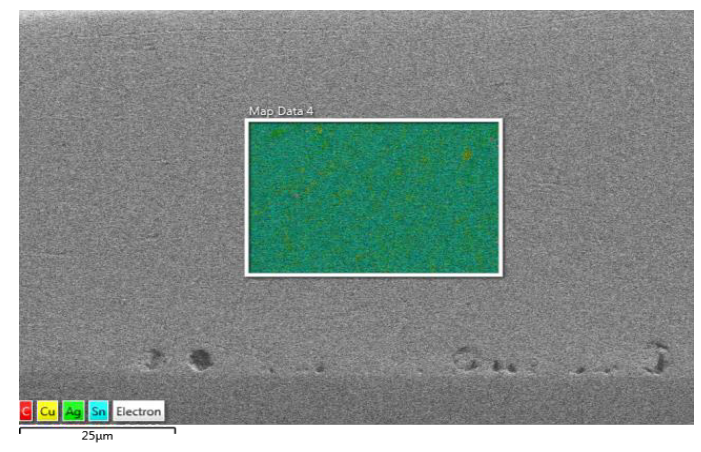

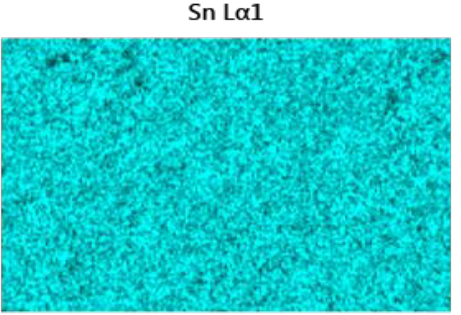

$10 \mu \mathrm{m}$

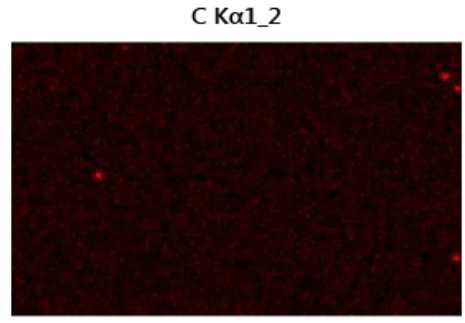

$10 \mu \mathrm{m}$
Ag L $\alpha 1$

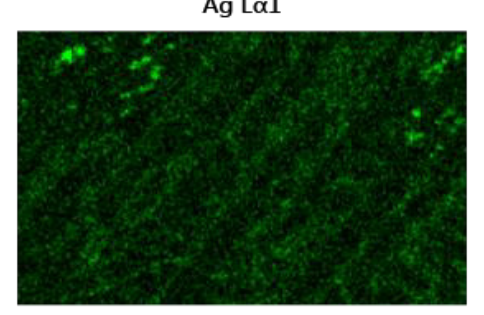

$10 \mu \mathrm{m}$

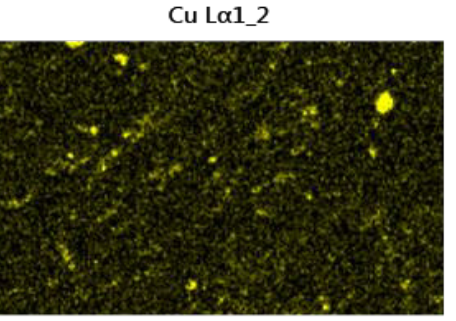

(a)

$10 \mu \mathrm{m}$ 


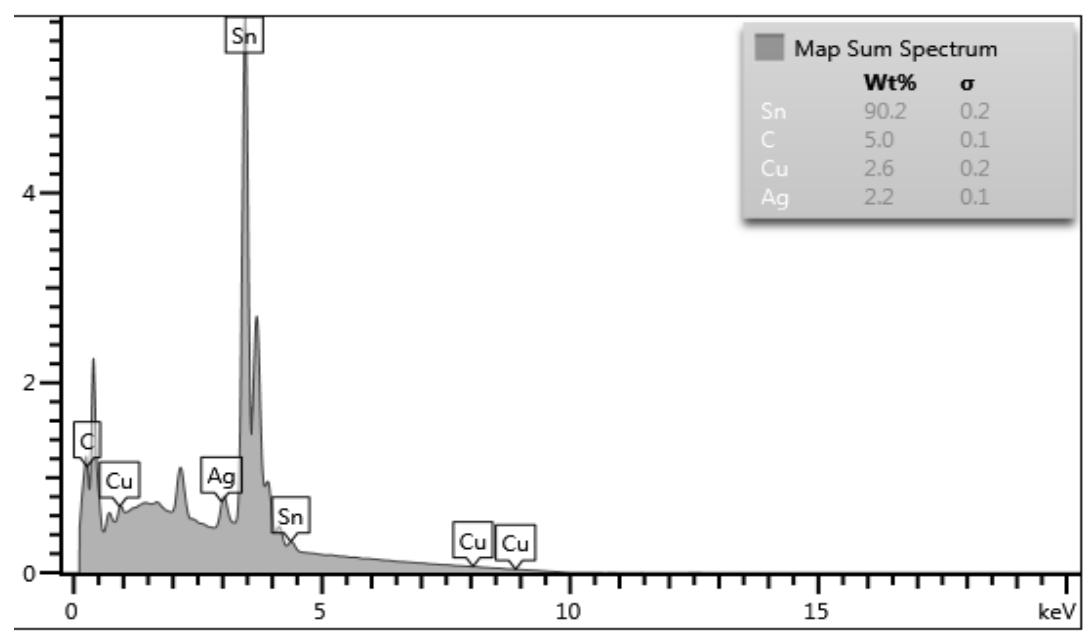

(b)

FIGURE 4. (a) FESEM image of SAC305-CNT solder joint with EDX mapping, and (b) corresponding EDX analysis

Figure 5 shows the loading-unloading $(P-h)$ profile of indentation on the SAC305 and SAC305-CNT solder joint for control sample and blast test sample. From the profile, indentation depth increased during the loading process and depth reached a maximum during the load holding time or known as dwell time (Jalar et al. 2020). SAC305-CNT solder joint indicates the lower values of maximum indentation depth compared to SAC305 solder joint for control sample and blast test sample. The values of maximum indentation depth for samples of SAC305-control, SAC305-blast test, SAC305CNT-control and SAC305CNT-blast test were $1062.8 \mathrm{~nm}, 1246.1 \mathrm{~nm}, 981.3 \mathrm{~nm}$, and $1118.5 \mathrm{~nm}$, respectively. Constant load behaviour can be seen from the indentation depth displacement profiles as shown in Figure 6. Indentation depth displacement corresponds to the change in indentation depth at $10 \mathrm{mN}$ peak load during $60 \mathrm{~s}$ holding time (Xu et al. 2018). Indentation depth displacement and percentage of displacement for each sample were indicated in Table 1. SAC305CNT solder joint for control sample and blast test sample show the lower percentage of indentation depth displacement compared to both SAC305 solder joint sample. It shows that addition of CNT reduced the indentation depth displacement of SAC305 solder joint for control sample and blast test sample about $\sim 42$ and $\sim 56 \%$, respectively. SAC305CNTcontrol and SAC305CNT-blast test shows the same trend of indentation depth displacement profile. The rate of displacement (slope of the curve in Figure 6) during the holding time under constant load was observed to be high for the initial stage and then decrease with the increasing holding time. The existence of CNT in the solder joint slows down the depth displacement due to constant load by retard the movement of indenter (Han et al. 2012).

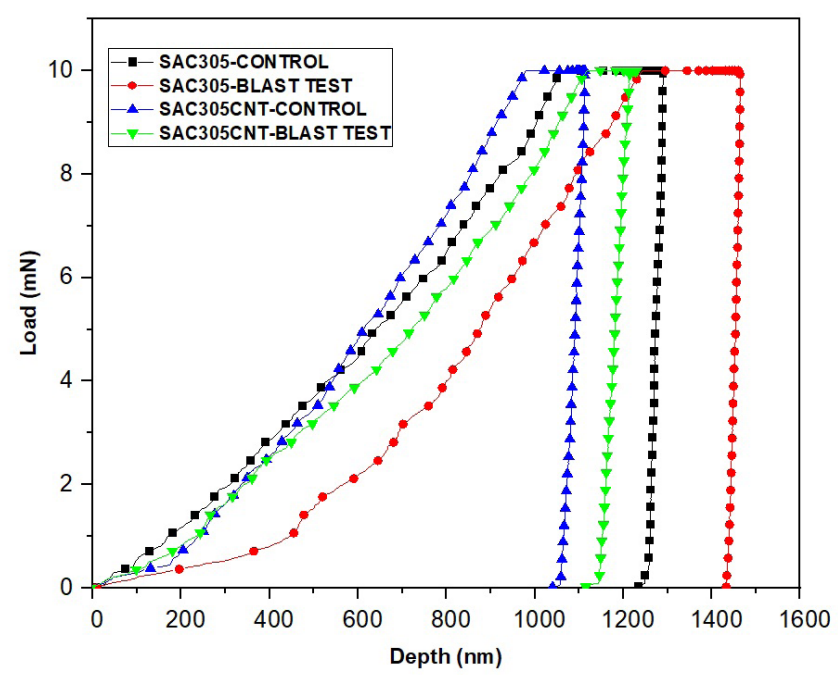

FIGURE 5. $P-h$ profile of nanoindentation for solder joint 


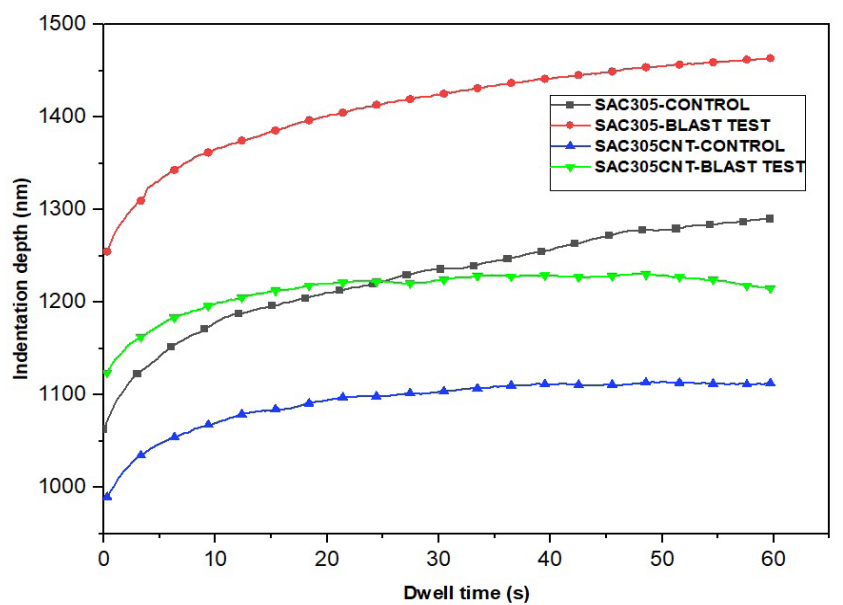

FIGURE 6. Indentation depth versus dwell time graph for SAC305 and SAC305-CNT solder joints under blast wave condition

TABLE 1. Indentation depth displacement and percentage of displacement for each sample

\begin{tabular}{lcc}
\hline Solder type & $\begin{array}{c}\text { Indentation depth } \\
\text { displacement }(\mathrm{nm})\end{array}$ & Percentage of displacement (\%) \\
\hline SAC305-control & $1062.6-1290.2$ & 17.64 \\
SAC305-blast test & $1246.1-1463.7$ & 14.86 \\
SAC305CNT-control & $981.3-1290.2$ & 23.94 \\
SAC305CNT-blast test & $1118.5-1214.9$ & 7.93 \\
\hline
\end{tabular}

From the indentation depth displacement curve, graph of $\log$ strain rate versus stress as shown in Figure 7 was plotted to determine the stress exponent (n) of flow stress for SAC305 and SAC305-CNT solder joints under shock wave condition. The log-log graph of strain rate versus stress is plotted using the equations as stated in experimental procedures. From the log-log graph strain rate versus stress, the stress exponent (n) can be obtained by linear regression fitting (Hasnine et al. 2017). Stress exponent values obtained was indicated in the Figure 8. From the Figure 8, it is noted that stress exponent for SAC305-CNT solder joint is higher than SAC305 solder joint. When expose to the blast wave the, SAC305-CNT shows the minimal change of stress exponent compared to SAC305 solder joint.

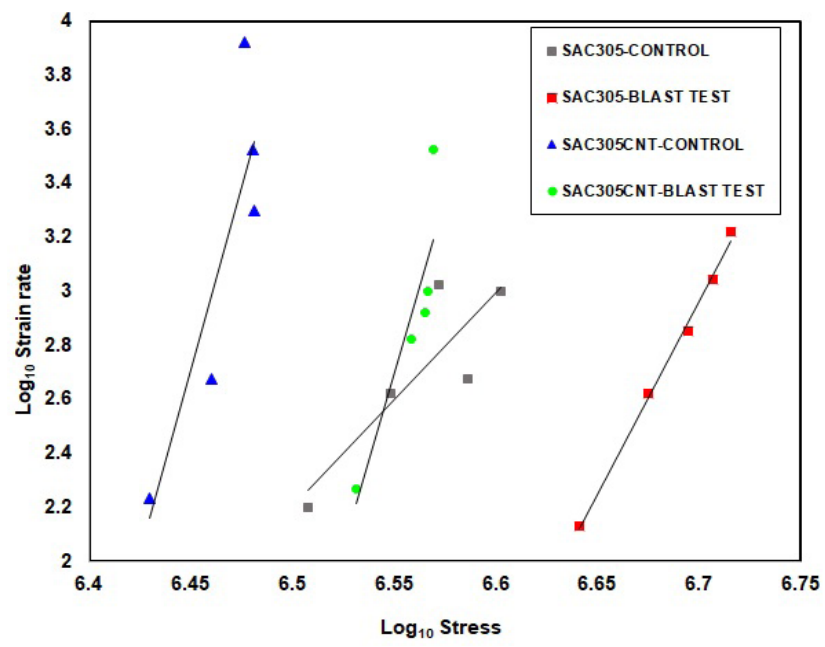

FIGURE 7. Plot of log stress rate $(\dot{\varepsilon})$ versus $\log$ stress $(\sigma)$ to determine the stress exponent, $\mathrm{n}$ of flow stress of nanoindentation test for the SAC305 and SAC305-CNT under blast wave condition 


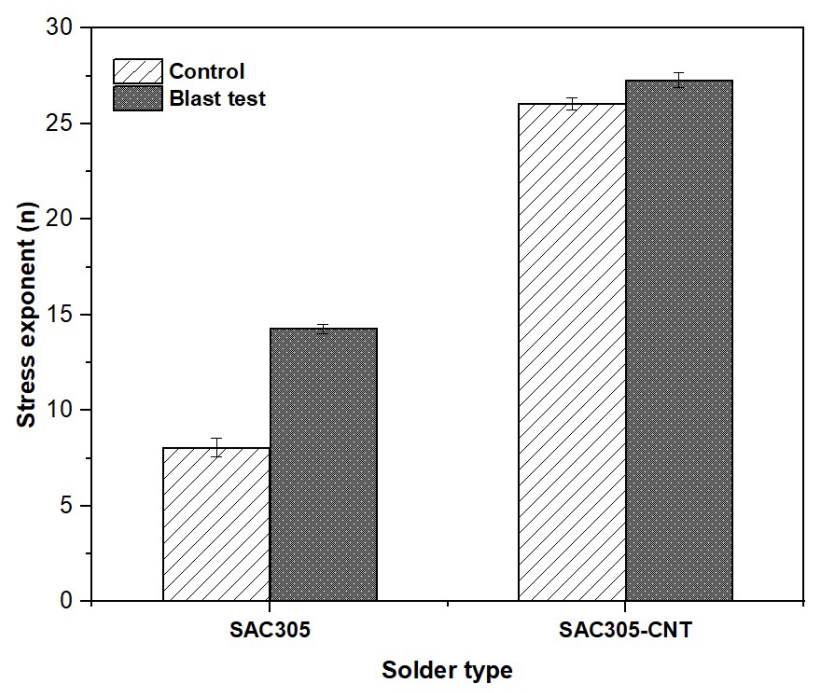

FIGURE 8. Stress exponent values of investigated solders

The stress exponent can be used to describe the deformation mechanism of the materials during the indentation due to the load applied. The value of stress exponent can determine the responsible deformation mechanism of the solder alloys ((Abdullah et al. 2018; Mahmudi et al. 2004). Commonly, $\mathrm{n}=1$ is associated with diffusion creep (by lattice or grain boundary diffusion), $\mathrm{n}=2$ with grain boundary sliding, and $\mathrm{n}>3$ with dislocation creep. As a result, for current investigated solder joint, deformation mechanism was dominated by dislocation creep (climb or glide) (Li et al. 2019). Higher stress exponent of SAC305-CNT solder joint is due to the higher dislocation generated by the addition of CNT in the solder matrix (Sadeghilaridjani \& Mukherjee 2020). High dislocation in SAC305-CNT prevent the occurrence of deformation during the blast wave exposure and resulted in small changes of stress exponent.

\section{CONCLUSION}

This paper presents the constant load behaviour of SAC305 solder joint with the addition of CNT under shock wave condition by nanoindentation approach. Exposure to the shock wave influence the indentation depth of SAC305 and SAC305-CNT solder joint at $10 \mathrm{mN}$ peak constant load. Indentation depth displacement of SAC305 solder joint with the addition of CNT for control sample and blast test sample are lower than indentation depth displacement of SAC305 which are about $\sim 42$ and 56\%, respectively. It was shown that existence of CNT in the solder joint slows down the indentation depth displacement by retard the movement of indenter. Stress exponent of SAC305 solder joint with addition of CNT is higher than stress exponent of SAC305 solder joint without CNT. When expose to the shock wave, the stress exponent value of SAC305-CNT have a minimal change compared to SAC305 solder joint. It suggested that high dislocation due to addition of CNT prevent the abrupt changes of deformation mechanism towards blast wave.

\section{ACKNOWLEDGEMENTS}

The authors are gratefully acknowledged for the financial support from Universiti Kebangsaan Malaysia (UKM) under MI-2018-019 grant and Universiti Pertahanan Nasional Malaysia (UPNM) under grant FRGS/1/2015/ SG06/UPNM/03/1, and Redring Solder (M) Sdn. Bhd. for research materials and collaboration work.

\section{REFERENCES}

Abdullah, I., Zulkifli, M.N., Jalar, A. \& Ismail, R. 2018. Deformation behavior relationship between tensile and nanoindentation tests of SAC305 lead-free solder wire. Soldering and Surface Mount Technology 30(3): 194-202.

Goodall, R. \& Clyne, T.W. 2006. A critical appraisal of the extraction of creep parameters from nanoindentation data obtained at room temperature. Acta Mater. 54: 5489-5499.

Han, Y.D., Jing, H.Y., Nai, S.M.L., Xu, L.Y., Tan, C.M. \& Wei, J. 2012. Creep mitigation in $\mathrm{Sn}-\mathrm{Ag}-\mathrm{Cu}$ composite solder with Ni-coated carbon nanotubes. J. Mater. Sci.: Mater. Electron. 23: $1108-1115$

Hasnine, M., Suhling, J., Prorok, B., Bozack, M.J. \& Lall, P. 2017. Anisotropic mechanical properties of SAC solder joints in microelectronic packaging and prediction of uniaxial creep using nanoindentation creep. Exp. Mech. 57: 603-614.

Huang, Y., Xiu, Z., Wu, G., Tian, Y. \& He, P. 2016. Sn-3.0Ag$0.5 \mathrm{Cu}$ nanocomposite solders reinforced by graphene nanosheets. J. Mater. Sci.: Mater. Electron 27(7): 6809-6815. 
Ismail, N., Jalar, A., Abu Bakar, M., Ismail, R., Safee, N.S., Ismail, A.G. \& Ibrahim, N.S. 2019. Effect of isothermal aging on microhardness properties of $\mathrm{Sn}-\mathrm{Ag}-\mathrm{Cu} / \mathrm{CNT} / \mathrm{Cu}$ using nanoindentation. Sains Malaysiana 48(6): 1267-1272.

Ismail, N., Jalar, A., Abu Bakar, M., Safee, N.S., Wan Yusoff, W.Y. \& Ismail, A. 2020. Microstructural evolution and micromechanical properties of SAC305/CNT/CU solder joint under blast wave condition. Soldering and Surface Mount Technology. doi/10.1108/SSMT-11-2019-0035.

Jalar, A., Bakar, M.A. \& Ismail, R. 2020. Temperature dependence of elastic-plastic properties of fine-pitch SAC 0307 solder joint using nanoindentation approach. Metallurgical and Materials Transactions A: Physical Metallurgy and Materials Science 51: 1221-1228.

Jiang, N., Zhang, L., Liu, Z., Sun, L., Long, W., He, P., Xiong, M. \& Zhao, M. 2019. Reliability issues of lead-free solder joints in electronic devices. Science and Technology of Advanced Materials 20(1): 876-901.

Kassner, M.E. 2009. Fundamentals of Creep in Metals and Alloys. 2nd ed. Oxford: Butterworth-Heinemann.

Kumar, K.M., Kripesh, V. \& Tay, A.O. 2008. Single-wall carbon nanotube (SWCNT) functionalized $\mathrm{Sn}-\mathrm{Ag}-\mathrm{Cu}$ lead-free composite solders. Journal Alloys Compound 450: 229-237.

Li, Z., Zhao, S., Ritchie, R.O. \& Meyers, M.A. 2019. Mechanical properties of high-entropy alloys with emphasis on facecentered cubic alloys. Prog. Mater. Sci. 102: 296-345.

Mahmudi, R., Roumina, R. \& Raeisinia, B. 2004. Investigation of stress exponent in the power-law creep of $\mathrm{Pb}-\mathrm{Sb}$ alloys. Mater. Sci. Eng. A. 382: 5-22.

Mallakpour, S. \& Khadem, E. 2016. Carbon nanotube-metal oxide nanocomposites: Fabrication, properties and applications. Chemical Engineering Journal 302: 344-367.

Niranjani, V.L., Vajinder Singh, Chandra Rao, B.S.S. \& Kamat, S.V. 2014. Creep behaviour of SAC387 lead free solder alloy reinforced with single walled carbon nanotubes. Trans. Indian Inst. Met. 68: 311-317.

Sadeghilaridjani, M. \& Mukherjee, S. 2020. High-temperature nano-indentation creep behavior of multi-principal element alloys under static and dynamic loads. Metals 10(2): 250.

Sun, L. \& Zhang, L. 2015. Properties and microstructure of $\mathrm{Sn}-\mathrm{Ag}-\mathrm{Cu}-\mathrm{X}$ lead-free solder joints in electronic packaging. Advances in Materials Science and Engineering 2015: Article ID. 639028.
Wan Yusoff, W.Y., Ismail, N., Safee, N.S., Ismail, A., Jalar, A. \& Abu Bakar, M. 2019. Correlation of microstructural evolution and hardness properties of $99.0 \mathrm{Sn}-0.3 \mathrm{Ag}-0.7 \mathrm{Cu}$ (SAC0307) lead-free solder under blast wave condition. Soldering and Surface Mount Technology 31(2): 102-108.

Xu, L.Y., Zhang, S.T., Jing, H.Y., Wang, L.X., Wei, J., Kong, X.C. \& Han, Y.D. 2018. Indentation size effect on Ag nanoparticle-modified graphene/Sn-Ag-Cu solders. Journal of Electronic Materials 47: 612-619.

Yang, L., Liu, H. \& Zhang, Y. 2018. Study on the tensile creep behaviour of carbon nanotubes-reinforced Sn-58Bi solder joints. Journal of Electronic Materials 47: 662-671.

Zhang, L. \& Tu, K.N. 2014. Structure and properties of lead-free solders bearing micro and nano particles. Materials Science and Engineering: R: Reports 82: 1-32.

Zhongbao, Y., Wei, Z. \& Ping, W. 2014. Effects of Ni-coated carbon nanotubes addition on the microstructure and mechanical properties of $\mathrm{Sn}-\mathrm{Ag}-\mathrm{Cu}$ solder alloys. Materials Science and Engineering A 590: 295-300.

Norliza Ismail \& Azman Jalar*

Department of Applied Physic

Faculty of Science \& Technology

Universiti Kebangsaan Malaysia

43600 UKM Bangi, Selangor Darul Ehsan

Malaysia

Norliza Ismail \& Azman Jalar*

Institute of Microengineering and Nanoelectronics (IMEN)

Universiti Kebangsaan Malaysia

43600 UKM Bangi, Selangor Darul Ehsan

Malaysia

Wan Yusmawati Wan Yusoff, Nur Shafiqa Safee \& Ariffin Ismail Pusat Asasi Pertahanan

Universiti Pertahanan Malaysia (UPNM)

Kem Sungai Besi

57000 Kuala Lumpur, Federal Territory

Malaysia

*Corresponding author; email: azmn@ukm.edu.my

Received: 13 August 2020

Accepted: 27 August 2020 